\title{
Trötta mammors försvarare: familje- värderingar i Kerstin Thorvalls bilderböcker från 1970-talet
}

http://urn.kb.se/resolve?urn=urn:nbn:se:sbi-35

Citation: Nordic Journal of ChildLit Aesthetics, Vol. 2, 2011 DOI: 10.3402/ blft.v2i0.5838

Abstract: Kerstin Thorvall (1925-2010) is a Swedish author of books for children and young adults, as well as books for adults. In 1965, she wrote the article "Do all authors of children's books live in Tomtebolandet?" ("Bor alla barnboksförfattare $i$ Tomtebolandet", Expressen 1965) in which she claims that gender roles in Swedish children's literature, are depicted in an old and stereotypical fashion. She also wants children's literature to adjust better to the actual lives of it's readers, for example by describing the environments that are recognizable to children in their everyday life, such as kindergarten and apartment buildings in an urban setting. Thorvall's article inspired a debate about children's literature and gender roles that had a great influence in the design of children's books in the following decade. Thorvall herself also wrote picture books showing her version of the best ways to handle these issues in children's literature. This paper will address some of these picture books, namely Mamma, var är du? (1972, Mother, where are you?) and the books about Sara, Sara (1975) and Mer om Sara (1977, More about Sara) with illustrations by Monica Schultz, in order to discuss issues about children's literature and it's depiction of family values during the Swedish 1970s.

Keywords: family values, gender roles, society, picturebooks, motherhood

1960- och 1970-talen var en omvälvande tid för svensk barn- och ungdomslitteratur. Barnlitteraturen togs på stort allvar och debatterades av såväl vuxen- som barnboksförfattare, liksom av en kulturellt bildad allmänhet. I 1960- och 1970-talens diskussioner om barnlitteraturens värden, som bland annat beskrivits i AnnaKarin 
Krisströms avhandling De gränslösa böckerna (publ. 2008) och i Lena Kårelands bok Inga gåbortsföremål (2009), befanns tanken om att möta barnet i en för barnet välkänd verklighet vara viktig. Sådana tankar uttrycktes också av Lennart Hellsing i den inflytelserika Tankar om barnlitteraturen (1963). Samtidigt gjorde sig krav på ett visst ideologiskt anpassat innehåll tydliga i vuxenlitteraturen såväl som i barnlitteraturen. Några av de fenomen som särskilt diskuterades var mäns och kvinnors könsroller samt litteraturens förmåga till verklighetsåtergivning.

Kerstin Thorvall var en av de författare som blev viktig för debatten om dessa fenomen i barnlitteraturen, i första hand genom debattartikeln "Bor alla barnboksförfattare i Tomtebolandet?" som publicerades i Expressen 1965. Artikeln startade en debatt som engagerade såväl viktiga författare som litteraturkritiker. Thorvalls roll som språkrör för en ny syn på verklighetsskildring och könsroller i barnlitteraturen gör det intressant att studera hur hon själv som författare och illustratör gick tillväga för att bädda för en förnyelse av barnlitteraturen på dessa plan. I den här artikeln kommer jag att diskutera dessa fenomen med utgångspunkt $i$ Kerstin Thorvalls (19252010) bilderböcker för barn. Det rör sig framför allt om böckerna Mamma, var är du? (1972), Sara (1975) och Mer om Sara (1979) med tonvikt på de två senare. Böckerna om Sara sändes i Sveriges televisions barnprogram innan de publicerades, och fick därför ett jämförelsevis starkt genomslag i samtiden vilket gör dem särskilt intressanta. Bland Thorvalls barnlitterära produktion är det främst ungdomsböckerna som fått uppmärksamhet inom tidigare forskning, medan bilderböckerna fortfarande är relativt outforskade.

Jag kommer även att lyfta fram några av de verkliga mödrar som porträtterades i tidningen Vi Föräldrar under ungefär samma tid som Thorvalls böcker gavs ut för att jämföra Thorvalls modersskildringar med dem. Tidningen utgör ett intressant jämförelsematerial, eftersom den ofta innehöll inslag som var utarbetade i samverkan med ledande skribenter och illustratörer inom barnlitteraturen. Eftersom tidningen riktar sig till en bredare allmänhet fungerar den också som en indikator om samhällsnormen när det gäller familjevärderingar under denna tid. Därför säger jämförelsen något om hur Thorvalls böcker förhåller sig till en samtida verklighetsuppfattning.

\section{Familjen under omförhandling}

Begreppet familj kan förstås som en symbolisk konstruktion vars innebörd förändras i samband med att den historiska kontexten 
och de verkliga familjesituationer som människor lever i förändras. Familjevärderingar är ofta "osynliga" i den bemärkelsen att de tas för givna vid ett specifikt historiskt ögonblick (Gillis 1996, xvii). De tenderar dock att bli synliggjorda vid tillfällen då de börjar ifrågasättas från flera olika håll samtidigt. Detta var exempelvis något som hände i Sverige under 1960-talet då gamla familjevärderingar togs upp till debatt och omförhandlades utifrån de nya samhälleliga förutsättningar som fanns.

Under 1950-talet rådde enligt reklambildernas estetik en harmonisk era för kärnfamiljen med den trygghetsskapande husmodern i en central position. Husmodern var starkt idealiserad och framställdes på många sätt som en garant för familjens fortsatta sammanhållning och trevnad. Det var först mot slutet av 1950-talet och i början av 1960-talet som olika röster på allvar började att ifrågasätta detta ideal (jfr Hirdman 1992, 199 ff). År 1961 kom Eva Mobergs debattartikel "Kvinnornas villkorliga frigivning" som bidrog till att medvetandegöra kvinnors förtryck i denna roll och behovet av en förändring. Den amerikanska författaren Betty Friedans bok The Feminine Mystique (1962, i svensk översättning 1968) var en uppgörelse med hemmafruidealet i den amerikanska efterkrigskulturen och fungerade också inspirerande för kvinnorörelsen i Sverige.

Könsrollsfrågan i samband med barnlitteraturen väcktes av Rita Liljeström, som i artikeln "Det skall börjas i tid" (1962) påpekade skillnaderna mellan en pekbok riktad till flickor och en riktad till pojkar. Medan föremål som lok, bil och flygplan fanns i pojkpekboken fanns bilder av tallrik, kläder och potta i flickpekboken. Flickornas intressen skulle tidigt riktas mot hemmet och familjen, blev slutsatsen, medan pojkarnas skulle riktas utåt, mot den stora världen. Liknande diskussioner om könsroller i barnlitteraturen fördes även i andra nordiska länder i början av 1960-talet (ToijerNilsson 1978, 16).

Med den redan nämnda debattartikeln "Bor alla barnboksförfattare i Tomtebolandet" (Expressen 1965) gav sig Kerstin Thorvall in i diskussionen och medverkade till att driva fram en ännu mer intensiv debatt. Thorvall efterlyste en mer vardagsrealistisk utformning av svenska bilderböcker och var i första hand kritisk till hur mammorna framställdes. Hon nämner till exempel Tove Janssons skildring av muminmamman:

Muminmamman, som är alla stora varma mödrars urbild. Alltid lugn och tröstande, klok och kärleksfull, full av förståelse för Muminpappans bravader. Den fasta klippan. Den mjuka famnen. Mamman. 
Men mammorna som läser om henne (för i verkligheten är det oftast mammorna, som står för högläsningen) är sällan identisk med sagomammorna. I stället är de trötta och stressade. Det pirrar i deras nerver, när det äntligen är kväll och de får ungarna i säng. Efter en dags yrkesarbetande utanför hemmet känner de att mycket fattas för att de ska orka vara riktiga mödrar. En hemmamamma känner ofta likadant, när hon efter dagens oavbrutna kontakt med tre minderåriga barn inte orkar svara på en fråga till. ("Bor alla barnboksförfattare i Tomtebolandet?", 1965)

Thorvall framhäver vikten av att rikta sig till mindre barn med framställningar som kan ge ett alternativ till de cementerade könsrollerna, eftersom "i skolåldern är det redan för sent" (Thorvall 1965). Som ett botemedel mot den påtalade bristen skrev hon själv ett antal vardagsrealistiska bilderböcker för barn som erbjöd alternativ till de traditionella familjemönster och förlegade ideal som hon såg i andras bilderböcker under samma tid.

\section{"Riktiga" mammor i Thorvalls bilderböcker}

Alla Thorvalls böcker för mindre barn från 1970-talet befinner sig på gränsen mellan bilderbok och kapitelbok när det gäller förhållandet mellan text och bild. Samtliga böcker, utom Mamma, var är du? (1972) innehåller långa textstycken kombinerade med många och ibland också mycket generöst tilltagna illustrationer. Den utförliga texten i böckerna placerar dem någonstans mitt emellan bilderboks- och mellanåldersboksgenrerna.

Böckerna kan ses som ett tillmötesgående av nya önskemål om "rapportböcker" för mindre barn, som uttrycktes på flera håll under 1960- och 1970-talen. Inom vuxenlitteraturen frodades rapportboksgenren som ett svar på ett synsätt där budskapet premierades och formen skulle anpassas efter detta budskap. Rapportboken fungerade som ett slags journalistisk undersökning av verkligheten och sådana inslag som intervjuer, dokument och personliga vittnesmål var centrala. Ofta fungerade författaren själv som jagberättare (Steiner 2006, 199). Författaren Siv Widerberg efterlyste och gav själv förslag till rapportlitteratur för barn genom boken Gertrud på daghem (1966, ill. av Kaj Beckman). Widerberg menade att även små barn behövde reportage om verkligheten och att bilderboken kunde fungera som ett medium för detta ändamål (Kåreland 2009, 210). I alla de böcker som Thorvall skrev för mindre barn finns ett liknande förhållningssätt och uttryck för en önskan om att skildra barn i en för barn igenkännbar verklighet. Även andra försök att skildra 
barns vardag på daghem på ett realistiskt sätt gavs exempelvis i Ulf Hultbergs och Behnn Edvinssons Lotta och daghemmet (1975), och i Gunilla Woldes Emmas dagis (1976). Om böckerna ifråga verkligen är att betrakta som rapportböcker kan ifrågasättas, men ambitionen att dokumentera ett förskolebarns vardag är uppenbar hos många bilderboksförfattare under denna tid och i detta hämtades inspiration från rapportboksgenren.

Som en direkt följd av debatten publicerades också, under 1970talet, en rad bilderböcker som problematiserade ett traditionellt sätt att se på könsroller. Exempel på detta är Sonja Åkessons (text) och Monica Schultz' (ill.) bok Mamman och pappan som gjorde arbetsbyte (1970) och Gunilla Bergströms böcker om Alfons Åberg med början i God natt Alfons Åberg (1972), där pappan ensam tar hand om barn och hushåll. Det bör också framhållas att man även inom vuxenlitteraturen behandlade dessa frågor. Debatten gav upphov till en ny form av realism där det ideologiska budskapet var centralt, vilket bidrog till att göra rapportboksgenren till en viktig genre överlag under 1970-talet.

Kännetecknande för Thorvalls berättelser för mindre barn är att de imiterar sagor i anslaget, trots att de skildrar barns vardag ur ett socialrealistiskt perspektiv. I själva rubriken till boken om Anders, Gonattsagor om Anders, nästan 4 (1974, med ill. av Ilon Wikland) ges en läsanvisning om att berättelserna bör betraktas som ett slags moderna sagor om verklighetens barn. Böckerna om Sara är också motiviskt indelade i kortare avsnitt eller kapitel, vilket gör det möjligt att läsa dem som samlade korta sagor om Saras liv. Att sagan finns med som referensram för fiktionen framhäver snarare kontrasten mellan traditionella sagor och Thorvalls berättelser. Läsaren uppmanas att jämföra berättelserna med exempelvis den av Thorvall kritiserade boken Tomtebobarnen (1910), av Elsa Beskow, och dra sina egna slutsatser.

Boken Mamma, var är du? (1972) inleds också med sagans formel "Det var en gång...": "Det var en gång en mamma som hade fem barn." Ovanför texten syns mamman och de fem barnen i en serieruta och i pratbubblan säger mamman: "Jag är mamman som har fem barn" (Ill.1). Anpassningen av innehållet till serieformatet tillför en effekt av att det som skildras "visas fram" samtidigt som det kommenteras av texten. Serieformatet ger även möjligheten att efterhärma ljudliga kvalitéer via pratbubblornas estetik. När barnen ropar på mamma förstärks det ljudmässiga tjat som mamman måste utstå genom pratbubblornas och ordens storlek och utformning $\mathrm{i}$ pratbubblorna och upprepandet av ordet "mamma", även i sammanhang där det inte förekommer någon text under bilden (Ill.2). 


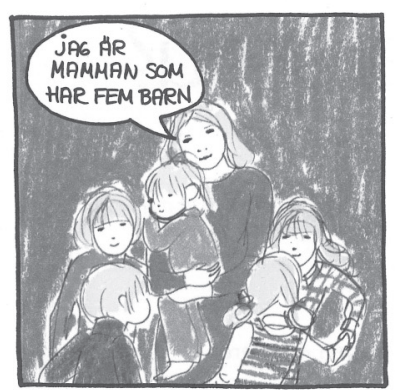

Det var en gång en mamma som hade fem barn.

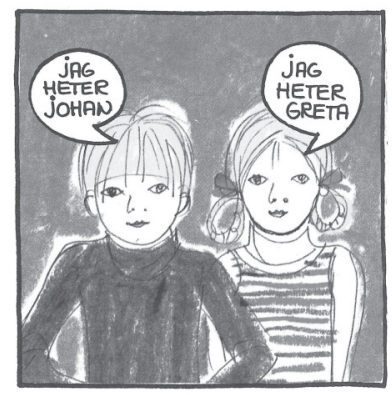

och Greta som var fem

och Johan, som också var fem, för dom var tvillingar,

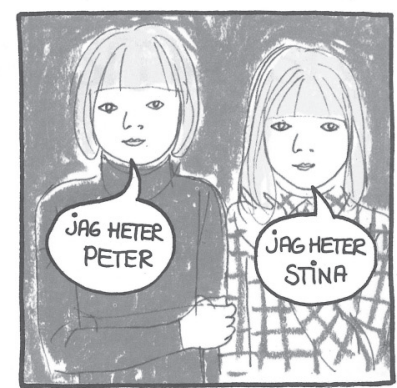

Det var Peter som var nio år och Stina som var sju,

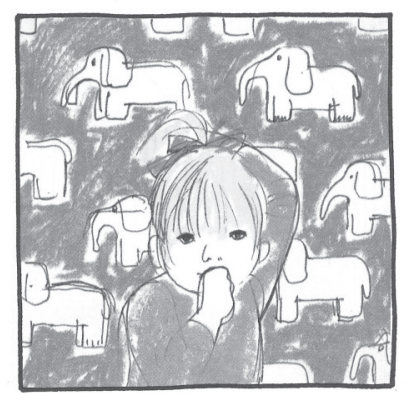

och så lilla Anna som bara var ett och ett halvt år.

III. I @ Kerstin Thorvall. Mamma, var är du? Stockholm: Rabén \& Sjögren, 1972.

När berättelsens mamma inte orkar med barnens tjat längre gömmer hon sig under ett rödblommigt täcke tillsammans med ett- och etthalvtåringen och svarar mekaniskt "jag vill inte" på alla barnens frågor. Lilla Annas slutliga "vill inte"-kommentar förstärker intrycket av att mamman har intagit barnets position och vägrar fortsätta vara den vuxne ansvarstagaren i den situation som uppstått. Det är också en symbolisk markör för det ögonblick i berättelsen då barnets och den vuxnes perspektiv i någon bemärkelse förenas: berättelsens budskap handlar om att få barnen att inse mammas, den vuxnas, perspektiv och att de genom sin empatiska inlevelseförmåga ska lära sig att själva ta på sig en del av ansvaret för arbetsfördelningen i familjen. De stora barnen tar på sig arbetsledarrollen och får de andra syskonen att arbeta tillsammans för att klara av sina egna problem och få mamma på bättre humör igen. 

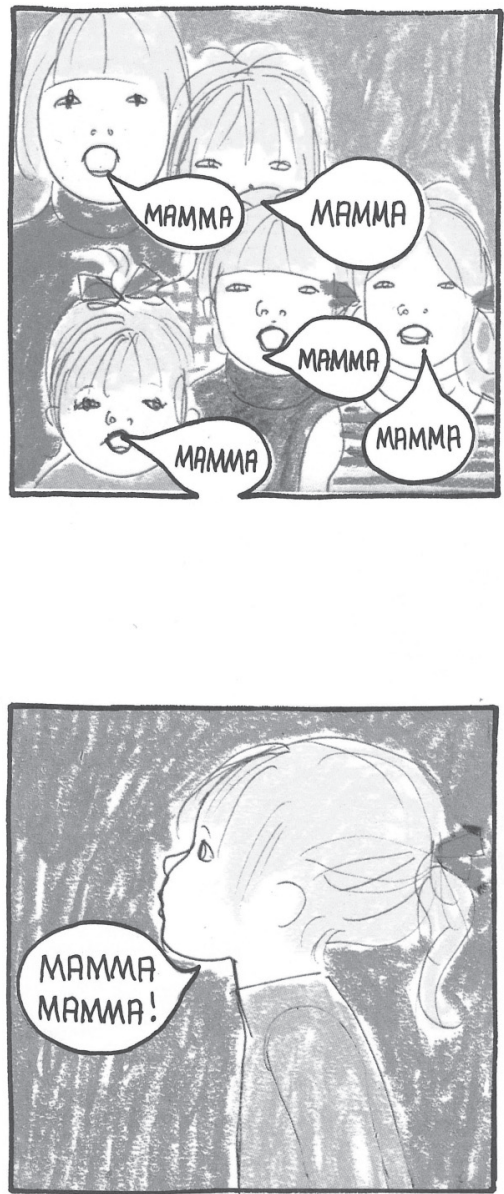

III. 2 @ Kerstin Thorvall. Mamma, var är du? Stockholm: Rabén \& Sjögren, 1972.
Böckerna om Sara, Sara (1975) och Mer om Sara (1977), skrevs båda av Kerstin Thorvall och illustrerades av Monica Schultz efter en förlaga i TVs barnprogram (också den med text av Thorvall och illustrationer av Schultz). Böckerna handlar om en flicka som är 5 år och bor tillsammans med sin mamma, som är frånskild från Saras pappa. Saras pappa har en ny familj tillsammans med Berit och lillebror Smulan. Böckerna om Sara förmedlar ett dagisbarns liv med betoning på det vardagliga.

I det första kapitlet introduceras Sara, Saras familjeförhållanden, Saras förskola och hennes hemmiljö för läsaren. Framför allt etableras (inte minst via bilderna) en samhörighet mellan Sara och hennes mamma. På den andra bilden, som tar upp en hel sida, sitter Sara och hennes mamma i nattkläder vid varsin sida av köksbordet och dricker samtidigt ur varsin kopp medan solen lyser utanför fönstret. På den sista heltäckande bilden i samma avsnitt sitter Sara och hennes mamma tätt intill varandra i soffan och badar fotbad i likadana baljor. De framställs också som mycket lika varandra utseendemässigt (Ill 3 och 4). Likheten skulle kunna tolkas som ett sätt att framhäva vikten av biologiska band mellan mor och dotter, men den tjänar i första hand som ett sätt att symboliskt förstärka intrycket av en annan slags samhörighet: Sara kommer en dag att växa upp till en kvinna som sin mor och då kommer hon att få en större insikt och förståelse för sin mammas situation som ensamstående förälder. Att Sara redan vid fem års ålder är så lik sin mamma poängterar för läsaren att hon kommer att bli vuxen en dag och förser också läsaren med en tolkning av hur hon då kommer att se ut.

I andra situationer skildras Saras mamma som en person med intressen som delvis ligger i konflikt med Saras egna. Bokens omslag är intressant eftersom den avbildar en traditionell familjeidyll med mamma, pappa och barn på svampplockningsutflykt i skogen. Av 
berättelsens handling förstår man emellertid snart att mannen på bilden omöjligt kan vara Saras pappa och så småningom visar det sig att mannen är en pojkvän till Saras mamma. I avsnittet "Svamputflykten" presenteras mannen som Olle: "Olle är mammas kille. Först tyckte Sara inte om honom. Först tyckte Sara att han var jättedum. Nu är han bara dum ibland. Eller om det är mamma som blir litet dum när Olle kommer." (Thorvall och Schultz, Sara 1975) Utflykten blir en trevlig tillställning tills mamma plötsligt inte svarar när Sara ber om en macka till:

\begin{abstract}
"Mamma", säger Sara igen och vänder sig om för att titta på mamma. Men då är inte mamma där. Joodå. På ett vis är hon det. Hon ligger där på filten, men hon syns knappt. Olle är lutad över henne och pratar något nära mammas ansikte. Något som bara mamma hör. Men det Sara säger det hör inte mamma. I varje fall svarar hon inte. Hon kan inte heller. För just nu kysser Olle henne mitt på munnen. Då vill inte Sara ha nån mer smörgås. (Thorvall och Schultz, Sara 1975)
\end{abstract}

Sara går iväg för att se om mamma och Olle upptäcker att hon är borta och svär för sig själv: "Djävlar djävlar". Mamma och Olle upptäcker till slut att Sara försvunnit och börjar ropa på henne. Berättelsen slutar lyckligt då Sara hittar ett bestånd med kantareller bakom busken där hon har gömt sig.

I en annan episod får Sara följa med mamma till jobbet eftersom hon är förkyld och det inte finns någon annan som kan passa henne. Efter att detillsammans gått igenom alternativen tvingas Saras mamma att resignera och ser trött ut: "'Nej, det blir nog ingen annan råd, än att du får följa med mig till affären', säger mamma sen och blir bråttom på ögonen". Men på mammas jobb måste Sara hålla sig undan och vara tyst så att hon inte stör mamma när hon betjänar kunder.

Saras mamma är ibland trött och stressad och låter sig även distraheras i umgänget med Sara av sådant som pojkvän och arbete. Dessa inslag framställs som små orosmoln på den blå himmel som Saras idylliska samvaro med sin mamma annars utgör. Det råder emellertid aldrig något tvivel om att mamman är en positiv kraft i Saras värld. I skildringen av relationen mellan Sara och hennes mamma uttrycks författarens och illustratörens vilja att skapa igenkänning hos sina läsare genom att berätta om de vardagliga förhållandena i ett (skilsmässo-)barns vardag. Samtidigt uttrycks, särkilt genom bilderna av Sara och hennes mamma, också en önskan om att skapa förståelse hos läsarna för mammans situation, såväl hos de vuxna (med)läsarna som hos barnen. 


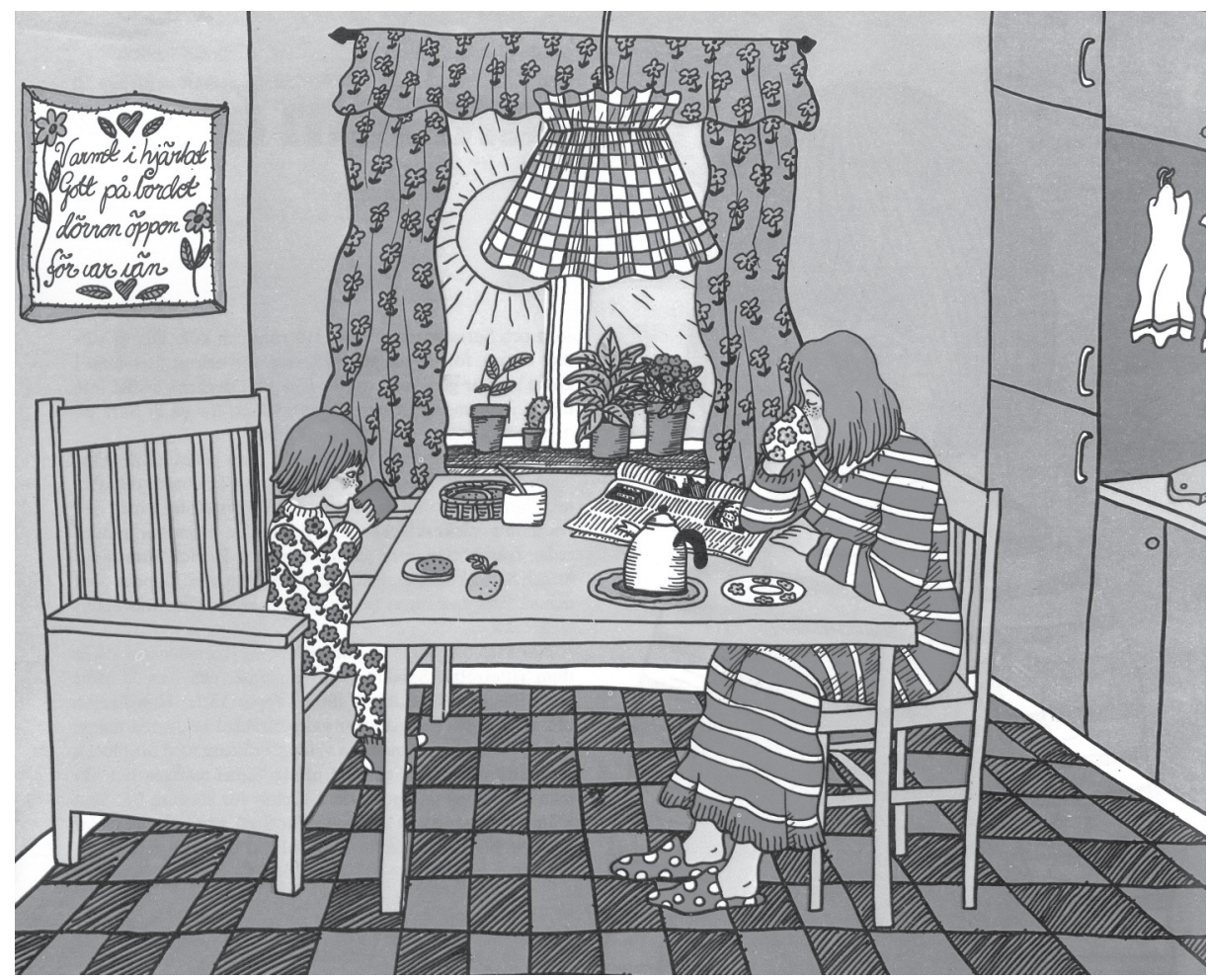

III. 3 Kerstin Thorvall och (C) Monica Schultz (ill.). Sara. Stockholm: Sveriges radio, 1975.

Det är i böckerna om Sara uppenbart att det inte går någon nöd på Sara, inte ens i de fall där mamma av någon anledning inte har tid med Sara. Då finns det andra människor där i stället som Sara känner sig trygg med. På detta sätt tycks berättelserna om Sara vilja visa upp den ensamma mamman som en positiv familjesituation, där såväl mamma som Sara mår bra och kan få den bekräftelse de behöver av varandra och av andra människor. Mamman i Mamma, var är du? framställs också i huvudsak som en trygg och positiv mamma, trots att hon väljer att avstå från föräldraskapets ansvar i några minuter. Thorvalls mammor är i dessa böcker de "trötta och stressade" mammor som hon i sin debattartikel menade inte kunde känna sig som "riktiga mammor" när de jämförde sig med sagornas modersgestalter. Genom att porträttera dessa verklighetsanpassade, men trots allt även lite idylliskt skimrande mammor i sina bilderböcker försökte hon förändra bilden av vad som skulle uppfattas som en riktig mamma, men också av vad som kunde uppfattas som en riktig familj. 


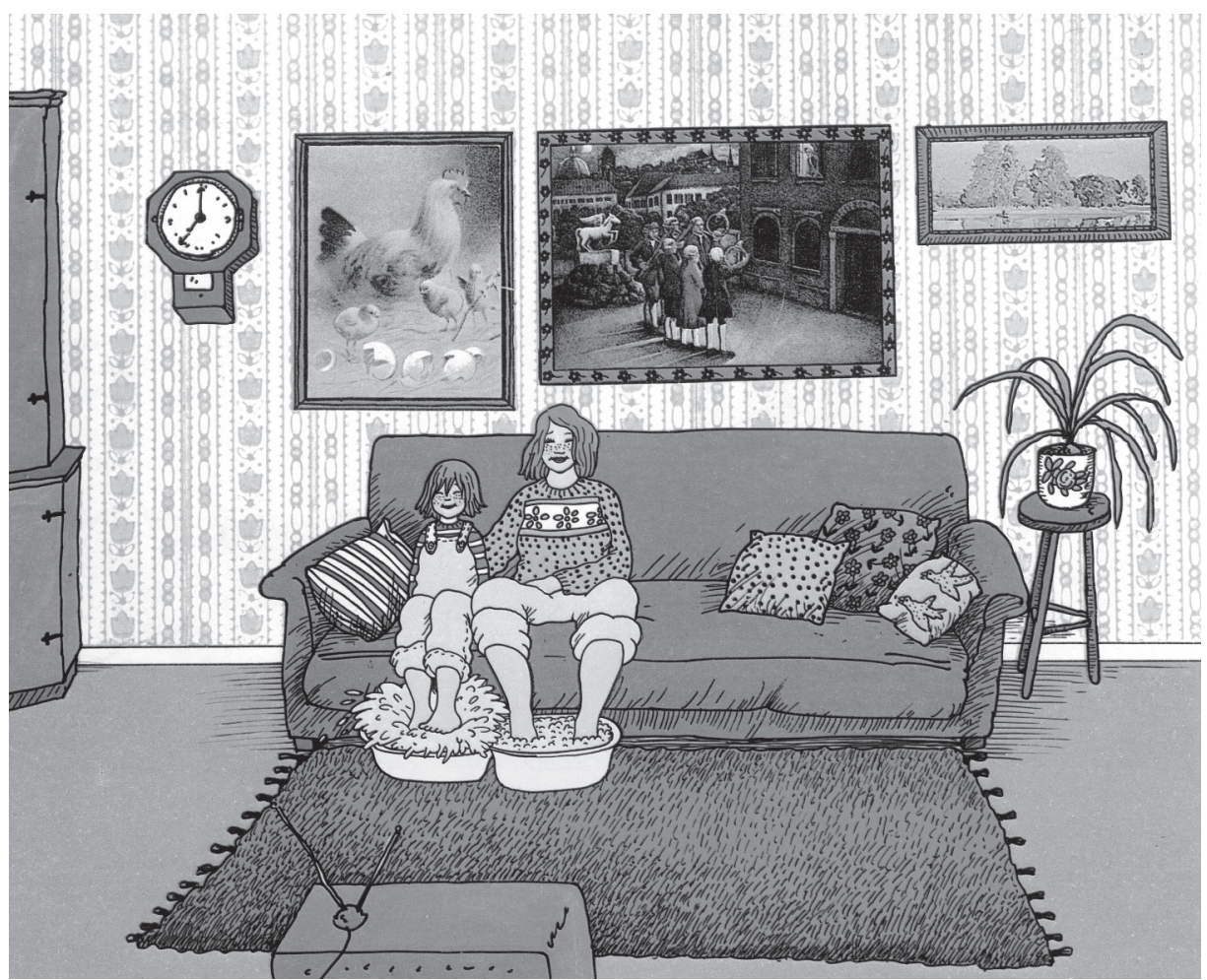

III. 4 Kerstin Thorvall och (C) Monica Schultz (ill.). Sara. Stockholm: Sveriges radio, 1975.

\section{Verklighetens mammor i tidningen Vi Föräldrar på 1970-talet}

Tidningen Vi Föräldrar startades 1968 med ambitionen att stärka föräldrar i sin roll och att försöka öka förståelsen mellan föräldrar och barn (Vi Föräldrar 1968: 1). Sedan starten har tidningen varit ledande bland specialtidningar om föräldraskap i Sverige och den har än idag en stark ställning inom området. Under 1970-talet var flera för samtiden välkända barnboksillustratörer verksamma i tidningen, som exempelvis Ilon Wikland, Pia Beckman, Barbro Hennius och Monica Schultz. Att just dessa illustratörer fanns med i tidningen kan möjligen förklaras genom deras ställning som socialrealismens gestaltare inom den samtida barnlitteraturen. Inte minst Ilon Wikland hade en framträdande roll när det gällde att estetiskt gestalta barns vardag. 1970-talets Vi Föräldrar var en tidning full av vilja till debatt. Mammors återinträde i yrkeslivet var en het fråga liksom det uppbrott detta innebar från det tidigare så starka hemmafruidealet. I bakgrunden kan man uttyda en stor oro över 
konsekvenserna av att många svenska mammor uppmanades att återgå till yrkeslivet efter föräldraledigheten och att "förverkliga sig själva" utanför familjen. Skulle barnen fara illa av att mammorna gav sig ut i samhället? Skulle männen gå med på den nya situationen och den nya arbetsfördelning av hemarbetet som den förde med sig? Skulle mammorna själva bli olyckliga? Tillhörande frågor som diskuterades var daghemmen - var de bra eller dåliga för barnen? Tillämpade de någon genomtänkt metod för uppfostran eller fungerade de bara som en dumpningsplats? Hur såg en dag för barnen ut på daghemmet eller hos dagmamman? - och papparollen - hur skulle männen finna sig i den nya roll de tilldelades i hemmet när arbetsfördelningen inte längre var lika självklar? Ytterligare frågor som hörde samman med huvudfrågan var ekonomi och kärleksrelationen mellan man och hustru.

Frågorna angreps i tidningen på olika sätt. År 1974 gavs en reportageserie i följetong där samma sex familjer återkommande intervjuades om allt från ekonomi och barnuppfostran till sexualliv. Vid flera tillfällen gjordes besök på olika förskolor och nya undersökningar om förskolan presenterades - bland annat Gunilla Ladbergs bok Daghem - förvaringsplats eller barnmiljö (1974) "som alla föräldrar och all daghemspersonal borde läsa!" enligt reportern Lena Lidbeck (Vi Föräldrar 1974, 9). Åtskilliga gånger infördes också särskilda temabilagor eller inlagor i tidningen under rubriker som "Om mamma börjar yrkesarbeta" (Vi Föräldrar 1970, 2) och "Den okände mannen" (Vi Föräldrar 1970, 5)

Tongångarna i mammornas egna berättelser om sin hemmasituation ekar emellanåt Betty Friedans tankegångar, som de presenteras i The Feminine Mystique. I temanumret "Om mamma börjar yrkesarbeta" uttalar sig Astrid, 36 år:

Alla säger jämt att jag borde vara tacksam. För att jag har det
så bra. Snäll man, friska barn, villa, bil, sommarställe. Men
jag kan väl inte bara gå omkring och vara tacksam jämt ... Jag
tycker det är så hemskt att känna mig som hemmafru. Det är
som en stämpel. Som om man bara vore ett bihang, ingen egen
person. (Vi Föräldrar 1970, 2)

Under rubriken "Rapport från en småbarnsmamma..." beskrivs en situation som påminner om fembarnsmammans i Thorvalls Mamma, var är du? Skribenten och Vi Föräldrar-läsaren, Margareta Johansson, börjar en dag anteckna hur många gånger barnen ropar "mamma" och kommer fram till att det rör sig om tjugotre gånger på en timme och tillägger sedan att hon umgås med sina barn tolv timmar om dagen. 


\section{Mamma! Mamma!}

MAMMA!!!

Efter frukost stänger äkta mannen dörren efter sig. Jag försöker dricka morgonkaffet samtidigt som jag brer sex smörgåsar, klipper ut tre bilder ur tidningar och släpper ut katten. Slår sedan ut det halvdruckna, kalla kaffet i vasken och går in på toaletten. Dit in, där man lär få sitta i egna tankar, kommer också 4-åringen med sax och tidning: "Mamma, klipp!" (Vi Föräldrar 1974, 9)

En tredje mamma berättar om sina känslor inför att hennes barn började prioritera sin pappa efter att hon återgått till yrkeslivet. För henne blev detta en upplevelse som avslöjar att hon fortfarande känner att hon måste leva upp till rollen som den perfekta föräldern, trots att hon själv valt bort hemmafrurollen: "[...]för kvinnan kvarstår en komplikation: hon kan visserligen ha lyckats ikläda sig sin nya roll ute i sitt arbete, men som mor släpar hon ännu på de gamla förväntningarna: om det mystiska i modersrollen, om att självklart vara den som betyder mest för barnet" (Vi Föräldrar 1974, 2).

De frustrerade mammorna i Vi Föräldrar kan betraktas som ett tidens tecken, som visar att förändringar i tidigare genusmönster var nödvändig men att dessa förändringar inte skulle kunna genomföras på något smärtfritt eller konfliktfritt sätt. I bilderböckerna för små barn som gestaltade detta slags "nya", "verkliga" mammor blev situationen oftast framställd med något utopiska förtecken. Allt slutar exempelvis väl i Sonja Åkessons och Monica Schultz Mamman och pappan som gjorde arbetsbyte med den enkla lösningen att mamma och pappa byter sysslor med varandra. I Thorvalls Mamma, var är du? är problemen också tillfälliga och övergående, i och med att barnen anammar den rätta förståelsen för mammans situation. I böckerna om Sara har den bullbakande modersfiguren hos äldre tiders barnboksförfattare bytts ut mot en realistiskt trött och jäktad mamma med egna behov att tillfredsställa, men enligt böckernas estetik och handling är detta inte något problem för Sara, utan endast orsak till mindre orosmoln. Den stora samhörigheten mellan mor och barn utgör trots allt en solid grund att vila på för båda parterna i relationen.

\section{Vad är en "riktig" familj?}

Tjugo år efter debattartikeln "Bor alla barnboksförfattare i Tomtebolandet?" konstaterade Thorvall att hon ofrivilligt kommit "att starta en nog så realistisk epok, det blev en övervikt av gråtande 
mammor och alkoholiserade pappor, och det var ju inte det jag direkt hade tänkt mig" (Thorvall i Furuland \& Ørvig 1986, 230). Thorvall ville gestalta en realistisk verklighet för små barn, men inte för den sakens skull tynga bilderboken med den sortens allvar som rapportböckerna för vuxna ofta ville visa. Hennes böcker visar att mammors och barns intressen inte alltid går ihop, men att detta inte behöver orsaka några stora bekymmer. Genom att mammans intressen tillgodoses blir även barnen lyckligare. Om ansvaret för familjen dessutom fördelas så att inte allt ligger på mammans axlar kan barnen också skapa starkare band till andra människor runtomkring dem.

För en läsare av idag kan skildringen av Saras mamma te sig ganska så konventionell, men under tiden för böckernas utgivning var den långt ifrån självklar. Böckerna målar upp ett alternativ till kärnfamiljen där modern visserligen fortfarande är central, men där hon också tillåts vara ensam och oberoende av ett förhållande till fadern. Till det nya med skildringen av Saras mamma hör också att hon inte tycks sträva efter att bilda en ny familj, i alla fall inte med någon brådska. Olle figurerar enbart i första boken och försvinner sedan från handlingen.

De familjevärderingar som kan läsas fram ur Thorvalls och Schultz två böcker om Sara bekräftar och bekräftas av de familjenormer som gestaltades i tidningen Vi Föräldrar under 1970-talet, även om tidningen naturligt nog erbjuder en större bredd när det gäller olika hållningar och olika familjekonstellationer. De harmoniserande tendenserna i barnlitteraturens realistiska skildringar av barns vardag och i Thorvalls böcker är en anpassning till den föreställda barnläsaren. Författarna tycks i många fall utgå från antagandet att vad barnen bäst behöver är att få höra att allt kommer att ordna sig - även om den som brukat få rollen av hemmets nav börjar yrkesarbeta så finns hon ändå tillhands, och dessutom finns det fler vuxna att tillgå. I den här bemärkelsen är det framför allt Thorvalls och Schultz böcker om Sara som uttrycker stöd för kvinnans yrkesarbete, medan mammorna i Gonattsagor om Anders, nästan 4 och Mamma, var är du? är hemma med barnen.

I tidningen Vi Föräldrar är tongångarna inte riktigt lika harmoniserande, utan utrymme ges åt såväl förespråkare för kvinnors yrkesarbete som för att kvinnor ska stanna hemma med barnen. Den vanliga förekomsten av barnboksillustratörer från en samtida barnboksutgivning kan emellertid vara ett sätt att ingjuta lite av den tillförsikt som ges i barnböckerna i tidningens läsare, som till stor del utgörs av samma slags trötta och godnattsagoläsande mammor som Thorvall skriver för. 
Biografisk information: Sara Kärrholm fil dr är lektor i litteraturvetenskap vid Språk- och litteraturcentrum i Lund och vid Konst, kultur och kommunikation vid Malmö högskola. Kontakt: sara.karrholm@litt.lu.se

\section{Bibliografi}

Furuland, Lars och Mary Ørvig. Ord och bilder för barn och ungdom 11: utblick över barn- och ungdomslitteraturen. Stockholm: Rabén \& Sjögren, 1986.

Gillis, John R. A world of their own making: myth, ritual, and the quest for family values. Cambridge: Harvard UP, 1997.

Hirdman, Yvonne. Den socialistiska hemmafrun och andra kvinnohistorier. Stockholm: Carlssons, 1992.

Johansson, Margareta. "Rapport från en småbarnsmamma". Vi Föräldrar (1974): 9: 68.

Kats, Madeleine. "Om mamma börjar yrkesarbeta". Vi Föräldrar (specialbilaga) (1970) 2: 36-47.

Kriström, AnnaKarin. De gränslösa böckerna: om Hans Alfredson och Barbro Lindgren i 60- och 70-talens allålderslitteratur. Diss., 2005. Skrifter utgivna av Svenska barnboksinstitutet, 101. Stockholm: Eriksson \& Lindgren. 2008.

Kåreland, Lena. Inga gåbortsföremål: lekfull litteratur och vidgad kulturdebatt $i$ 1960- och 1970-talens Sverige. Göteborg \& Stockholm: Makadam, 2009.

Ramel, Mette. "Svartsjuka om barnet - finns den?". Vi Föräldrar (1974) 2: 22-23 och 53.

Steiner, Ann. I litteraturens mittfåra: månadens bok och svensk bokmarknad under 1970-talet. Göteborg \& Stockholm: Makadam, 2006.

Thorvall, Kerstin. "Bor alla barnboksförfattare i Tomtebolandet?". Expressen, 1965-06-29.

Thorvall, Kerstin. Mamma, var är du? Stockholm: Rabén \& Sjögren, 1972.

Thorvall, Kerstin och Ilon Wikland (ill.). Gonattsagor om Anders, nästan 4. Stockholm: Rabén \& Sjögren, 1974.

Thorvall, Kerstin och Monica Schultz (ill.). Sara. Stockholm: Sveriges radio, 1975.

Thorvall, Kerstin och Monica Schultz (ill.). Mer om Sara. Stockholm: Sveriges radio, 1977.

Toijer-Nilsson, Ying. Berättelser för fria barn: könsroller i barnboken. Skrifter utgivna av Svenska barnboksinstitutet, 10. Stockholm: Stegelands, 1978.

Note: This article is being published simultaneously in Barnboken - tidskrift för barnlitteraturforskning/Journal of Children's Literature Research and Nordic ChildLit Aesthetics/Barnelittercert forskningstidsskrift 